\title{
Sustainability as a place brand position: a resident-centric analysis of the ten towns in the vicinity of Bangkok
}

\author{
Viriya Taecharungroj ${ }^{1} \cdot$ Morakot Muthuta $^{2} \cdot$ Pheereeya Boonchaiyapruek $^{3}$
}

Revised: 12 January 2019 / Published online: 13 June 2019

(c) The Author(s) 2019

\begin{abstract}
A number of cities and towns have used sustainability as a brand position, but most appear to have focused on the environmental aspect of sustainability, while the adoption of other dimensions of sustainability, including social and economic, has been limited. The objective of this study is to create a branding tool that can help towns develop a brand position that is credible, drives growth, involves residents and fosters sustainability. This sustainable place branding analysis was adapted from the importance-performance analysis widely used in business and in the tourism industry. The data were collected from the residents of ten towns in the vicinity of Bangkok, Thailand. The tool provides mayors with a holistic analysis of sustainability, suggests dimensions to be considered in the brand position and guides strategic actions to sustainably develop places. From the findings, the authors suggest five types of sustainable towns that the mayors of the ten towns can adopt as a brand position: elegant, compassionate, lively, peaceful and green.
\end{abstract}

Keywords Place sustainability $\cdot$ Place branding $\cdot$ Place brand positioning $\cdot$ Town branding $\cdot$ Thailand

\section{Introduction}

Sustainability is a concept that addresses the impact that humans have on the earth (Egger 2006). However, the relationship between sustainability and place branding has received little attention (Maheshwari et al. 2011) and thus

Electronic supplementary material The online version of this article (https://doi.org/10.1057/s41254-019-00127-5) contains supplementary material, which is available to authorized users.

Viriya Taecharungroj

viriya.tae@mahidol.edu

Morakot Muthuta

morakot.mu@kmitl.ac.th

Pheereeya Boonchaiyapruek

boonchaiyapruek_p@su.ac.th

1 Mahidol University International College, 999

Phutthamonthon 4 Road, Salaya, Nakhonpathom 73170,

Thailand

2 Faculty of Liberal Arts, King Mongkut's Institute of Technology Ladkrabang, Thanon Chalong Krung, Lat Krabang, Khet Lat Krabang, Bangkok 10520, Thailand

3 Faculty of Architecture, Silpakorn University, 31, Na Phra Lan Road, Phra Borom Maha Ratchawang, Phra Nakhon, Bangkok, Thailand requires more investigation (Govers et al. 2017). Nevertheless, the linkage between sustainability and place branding is not entirely new. A number of cities and towns have used sustainability as a brand position, but most of these places appear to have focused on the environmental aspect of sustainability, while the adoption of other dimensions of sustainability, including social and economic, has been limited (Zavattaro 2014). Zavattaro (2014) encouraged cities and towns to position the place brand by taking a holistic view of sustainability. Place brand positioning is a concept that involves the creation and ownership of a credible, valuable and distinctive position in the minds of that place's customers, which can lead to customer satisfaction, loyalty and competitive advantage (Fuchs and Diamantopoulos 2010; Gwin and Gwin 2003; Thompson 2003). Such a position often occurs in a concise form, such as a definitive statement, a memorable phrase or a short paragraph (Fan 2014). The ultimate aim of this study is to discover more ways to position a place brand using sustainability. Positioning and developing a place sustainably are beneficial for that place because sustainability leads to many positive outcomes such as resilience, self-reliance and positive externalities (Andersson 2006; Camagni et al. 1998; Childers et al. 2014; Pickett et al. 2013). 
A good example of positioning a place using sustainability is Vancouver, which has ambitiously implemented its "Greenest City Action Plan" in order to stay at the leading edge of urban sustainability (Walker 2016). The audacious claim of being the greenest city is not without support: Vancouver has been ranked highly in several popular lists such as third in the Economist's Global Liveability Ranking (Economist Intelligence Unit 2016) and first in the World Economic Forum's Green View Index (Willige 2017). Another example is the capital city of Norway: through extensive stakeholder engagement, Oslo assumed a position as a young pioneering city (Project Oslo Region 2015). This position both aspires to growth and maintains credibility because the population of Oslo is young and well educated; furthermore, this position is not actively held by other cities (Project Oslo Region 2015). These are two successful examples of global cities that assumed an aspirational and credible position, which are important characteristics of a good brand position (Insch 2014). Furthermore, although Oslo and Vancouver have taken different positions, both are part of a sustainability narrative that has become increasingly important in place branding and management.

However, the brand positioning of places is a challenging task because most places have resource constraints and coordination problems (Insch 2014). The Oslo project required enormous resources and extensive activities, including seminars, workshops, in-depth interviews, Internet surveys and meetings. Many places, especially smaller towns worldwide, may have limited access to the resources needed to meticulously develop a place brand position. The small towns and cities in the vicinity of Bangkok, the capital of Thailand, are one such example. The vicinity of Bangkok includes the six provinces of Nakhon Pathom, Pathum Thani, Nonthaburi, Samut Sakhon, Samut Prakan and Chachoengsao. These small cities and towns do not have sufficient resources for an extensive brand-strategy formulation. As such, they can benefit from a less resource-intensive approach to help develop their brand positions. Additionally, these provinces are at risk of sprawling development from Bangkok. As noted in previous research, sprawl is likely to cause dependence on automobiles, increased fuel consumption and deteriorating health of the people who live in the area (Sturm and Cohen 2004; Vandegrift and Yoked 2004). These potential problems are the utmost concern of sustainable development.

Therefore, the objective of this study is to develop a tool that can help small cities and towns such as these, which have limited resources and face threatening sustainability challenges, analyse various sustainability dimensions from the perspectives of their residents and infer an appropriate brand position using dimensions of sustainability. This study's findings can help bridge the gap between place branding and sustainability both theoretically and practically. To achieve the aforementioned objective, this study creates a practical and simple branding tool that can help places develop a brand position that is credible, drives growth, involves residents and fosters sustainability. To ensure generalisability and theoretical soundness, the authors drew upon knowledge from the fields of sustainability and management to develop this tool. The proposed sustainable place branding analysis (SPBA) is an adaptation of the popular importance-performance analysis (IPA), which is a widely accepted method in tourism management and other disciplines to identify improvement priorities and suggest strategic actions to enhance competitiveness (Azzopardi and Nash 2013; Matzler et al. 2003). The scope of this research is the ten towns under the responsibility of ten municipalities, which are the local governments in the six provinces in the vicinity of Bangkok. From the analysis of SPBA, the authors suggest the types of sustainable town positions that the ten towns in this study can take.

\section{Sustainability and place branding}

Sustainability is a concept that has two key features: intraand inter-generational equity and the three pillars. Intergenerational equity is the notion that the processes taking place today should have positive impacts while reducing negative effects on future generations (Jepson 2001). Intragenerational equity concerns the allocation of resources and affects the well-being of people within other groups as well as across species (Campbell 1996; Dassen et al. 2013; Jepson 2001). The second feature of sustainability is the famous three pillars, often referred to as the triple bottom line: environmental quality, economic prosperity and social justice (Mori and Christodoulou 2012). In the context of place management, the sustainability of places, or place sustainability, is a concept that seeks to understand and contribute to positive ecological, societal, economic and other processes in places (Pickett et al. 2013; Taecharungroj et al. 2018). Place sustainability is a complex issue because it concerns the interactions among various and intertwined elements such as the built environment, nature and humans within cities and towns (Campbell 1996). The previous literature has identified many dimensions of place sustainability; Ahvenniemi et al. (2017) identified dimensions that include the natural environment, built environment, water and waste management, transport, energy, economy, education, well-being, health and safety and governance and citizen engagement. This paper adopted 11 prominent dimensions in place sustainability according to Taecharungroj et al. (2018) because that paper includes a scale that can be used to measure the perceived sustainability of towns' residents:

- Natural environment sustainable places have effective natural environmental protection and residents who 
appreciate the natural environment (Chiesura 2004; Pickett et al. 2013). Such places also prevent deforestation and deterioration caused by urban development (Berke and Conroy 2000; Egger 2006).

- Economic growth to thrive in the future, sustainable places should promote innovation, encourage economic clusters and foster a comparative advantage for local businesses (Egger 2006; Jenks and Jones 2009).

- Social equity sustainable places must also improve the conditions of low-income members by including affordable housing and promoting social interaction (Berke and Conroy 2000; Jepson and Edwards 2010).

- Built environment sustainable places maintain a compact built environment, encourage the mixed use of land and facilitate efficient development (Jepson and Edwards 2010; Kenworthy 2006).

- Landscape sustainable places must also be beautiful, visually appropriate and accessible (Berke and Conroy 2000; Kenworthy 2006).

- Liveability and health sustainable places should have a stable environment that protects residents from external risks (Dassen et al. 2013) and should provide adequate shelter for residents (Egger 2006). They should also promote physical and mental health (Pickett et al. 2013).

- Conviviality sustainable places also have a safe environment that offers space for gathering (Dassen et al. 2013) and promotes social and cultural activities (Egger 2006).

- Transport sustainable places should also have wellconnected, affordable and green transportation systems (Jabareen 2006; Jepson 2003).

- Energy sustainable places must also have sufficient renewable energy usage and production such as passive solar design (Bruff and Wood 2000; Dassen et al. 2013; Jabareen 2006).

- Water and waste management sustainable places should have good processes for monitoring water quality, reusing water and recycling waste (Egger 2006; Jenks and Jones 2009; Shen et al. 2011).

- Governance sustainable places should also have processes that promote involvement and participation by residents, experts and other stakeholders (Jepson 2003; Zeemering 2009).

Despite the relative lack of research connecting place branding and sustainability, these two concepts are not entirely alien to each other. In the past, several studies have attempted to bridge the gap between place branding and sustainability (Acharya and Rahman 2016; Maheshwari et al. 2011). For example, Pant (2005) studied how the "Armenia experience" can attract and delight visitors and investors by focusing on the process of requalifying habitat and human capital through a set of environmental and social policies. New Norcia, a town in Western Australia, achieved a balance between economic need and maintenance of the traditional monastic lifestyle and brands itself accordingly (Ryan and Mizerski 2010). Bogotá, the capital of Colombia, is another excellent example of how sustainability was enhanced leading to the city receiving both international and national press attention and accolades (Kalandides 2011). In the case of Bogotá, a major development took place in the form of developing the built environment, such as redesigning public parks, repairs to sidewalks and urban renewal programmes. Among other aspects, they also improved social equity through the so-called "demarginalisation" programme, which aimed to improve the livelihood of people in the poorer informal settlements (Kalandides 2011).

Although some places do not deliberately use the term sustainability in their brand position, they have adopted one or more dimensions of place sustainability as their foundation. Considering the natural environment, Denver, a city in Colorado, launched the Greenprint Denver plan in 2006 to position itself as a leading city in sustainability. Vancouver's Greenest City action plan is another example of a place that positioned itself by emphasising the natural environment dimension of place sustainability. Chan and Marafa (2016) studied Hong Kong and proposed a branding framework that utilised the "green resources" of the city. The landscape is another dimension of place sustainability that has been used for branding purposes. de San Eugenio Vela et al. (2017) illustrated the relationship between a beautiful landscape and place branding by showing the example of how the people of New Zealand told stories about their country using the visual landscape.

With a concrete roadmap from the government, Germany is currently pioneering its energy transformation-energiewende-to position the country as a leader in energy production from renewable resources (Kunzig 2015). Although energiewende is not a traditional branding campaign, the impact and the success of its strategies have substantially strengthened Germany's brand, as reported in several news outlets (Ball 2017; Kunzig 2015). A well-connected and efficient urban transport system can also be used to brand a place. London is a prime example, as the London Underground is used as a tool to brand the city. The map of the London Underground is often referred to as a modern icon and a symbol of London (Vertesi 2008). It was estimated that more than 95 percent of Londoners have a copy of their endearing “Tube Map" at home (Vertesi 2008).

Some places have adopted economic growth as their brand position. Dubai is an excellent example of how a city can use a dynamic economy, wealth, sophistication and innovation as its brand position to attract visitors, residents and investors alike (Lee and Jain 2009). Dubai has also implemented several advertising strategies to reinforce this position. Another city that focused on economic growth is Turin (Torino), Italy. Turin has a long heritage 
as an industrial Fordist town. Their branding project aimed to position Turin as a creative city by blending the Fordist heritage with a celebration of culture through the campaign "Passion Lives Here" (Vanolo 2008). In the case of Turin, the term "passion" denoted the conviviality of the place.

Conviviality, or the joviality and sociability of a place, has also been used as a brand position for many places. For example, Barcelona adopted the conviviality or the life of its Raval District to position itself as a cultural city (Rius Ulldemolins 2014). Likewise, to position Beijing as liveable and convivial, the central government of China attempted to brand the city as an international megalopolis. They wanted Beijing to be perceived as a cultural centre and a city suitable for human habitation by famously centring their branding effort in the 2000s around the 2008 Olympic Games (Zhang and Zhao 2009). However, one drawback of such activities was that the residents of Beijing did not recognise the image projected by the government. Residents felt that the branding effort emphasised the city's promotion to tourists rather than its positioning based on traditional values and culture (Zhang and Zhao 2009).

The aforementioned examples demonstrate how many places on various levels, districts, cities and nations, use dimensions of sustainability to position a brand. These examples have different and often extensive methods to define a contextualised place brand position (Kalandides 2011; Lee and Jain 2009; Rius Ulldemolins 2014). Although these approaches are tremendously valuable for places, many small towns and cities may not have sufficient resources to undertake the extensive branding project. Therefore, this research develops a simple yet practical tool that can help mayors, place brand managers or government officials to evaluate the sustainability dimensions of their places and infer an appropriate place brand position. The formulation of SPBA is explained in the next section.

\section{The sustainable place branding analysis (SPBA)}

This proposed tool was adapted from the importance-performance analysis (IPA), which is widely used in business and in the tourism industry (Azzopardi and Nash 2013). The IPA identifies the attributes of a product, service or place along importance and performance axes (Matzler et al. 2003). IPA is a useful tool because it can help managers prioritise which attributes should receive more attention and which of them may consume too many resources (Matzler et al. 2003). The IPA is a simple diagnostic decision tool that facilitates prioritisation, allows managers to mobilise and deploy resources and harmonises strategic planning to enhance competitiveness (Azzopardi and Nash 2013). The IPA divides all attributes into four quadrants: keep up the good work (sustain resources), potential overkill (curtail resources), low priority (no change in resources) and concentrate here (increase resources) (Azzopardi and Nash 2013). However, the main difference between sustainability dimensions and product and service attributes is that it is not advisable to neglect any sustainability dimensions. Sustainability involves dynamic and balanced processes to ensure and enhance natural, economic and societal resources and capacity (Camagni et al. 1998). Therefore, the new SPBA, depicted in Fig. 1, places more emphasis on the strategic actions directed towards those dimensions of place sustainability than on the adjustment of resources.

SPBA involves three main actions that mayors can take, including "brand", "educate" and "improve". The tool assesses and categorises sustainability dimensions based on the residents' perceived performance and importance. The sustainability dimensions that fall within the "brand" section of the chart can be used as a foundation for developing a brand position. It is appropriate to position the place brand using the sustainability dimensions
Fig. 1 Sustainable place branding analysis (SPBA)

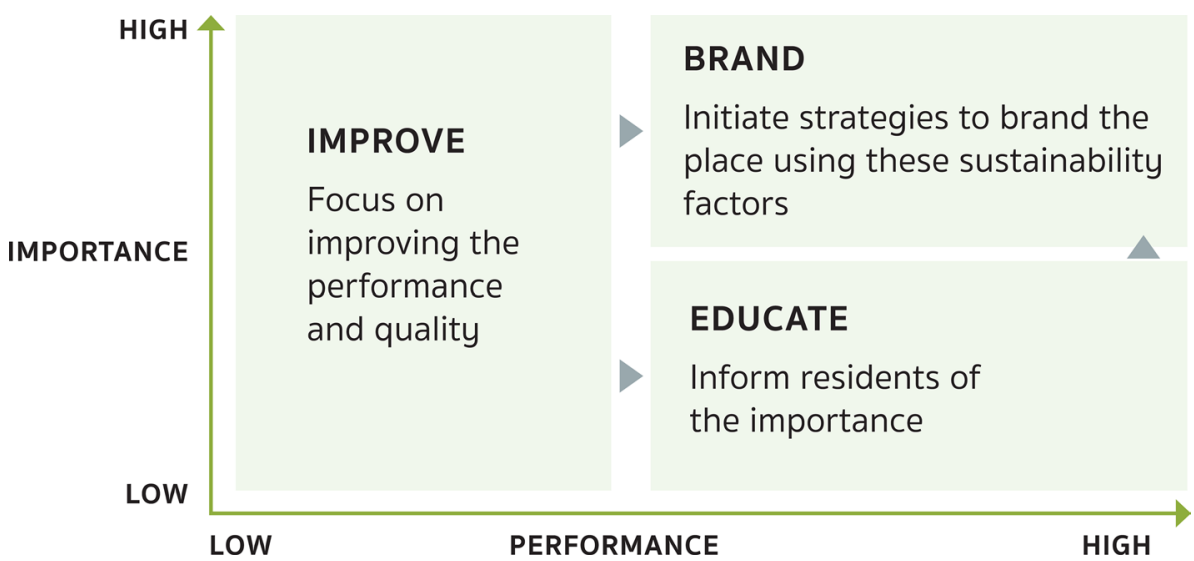


in this section because their rating denotes high performance, which makes the brand position credible, and high importance, which drives growth. The dimensions that fall within the "educate" section are of high perceived quality but low in importance. Mayors are encouraged to educate residents about the importance of these dimensions, but massive improvement projects might not be necessary. The left side of the chart is the "improve" area. Mayors should focus on improving the quality of these dimensions. The results of the SPBA analysis could help answer the research question: "what is an appropriate brand position for the ten towns according to SPBA?"

\section{Methodology}

To select the towns in Bangkok's vicinity, the authors categorised municipalities-local government agencies responsible for the management of cities and towns-based on the province in which they are located, the type of the municipality and the population density. Two municipalities each were selected from four of the six provinces-Samut Prakan, Nonthaburi, Nakhon Pathom and Pathum Thani. One municipality each was selected from Samut Sakhon and Chachoengsao because compared with the other four, these provinces have lower populations. There are three types of municipality in Thailand, depending on the area's size and population: the city municipality (Thedsaban Nakhon), town municipality (Thedsaban Muang) and subdistrict (Thedsaban Tambon). Within these six provinces, there are 7 city municipalities, 22 town municipalities and 101 subdistrict municipalities. Finally, the selections also represent towns with varying degrees of density, including high density (higher than 5000 population per $\mathrm{km}^{2}$ ), upper-middle density (3000-4999 population per $\mathrm{km}^{2}$ ), lower-middle density (1000-2999 population per $\mathrm{km}^{2}$ ) and low density (lower than 1000 population per $\mathrm{km}^{2}$ ). The final ten selections that fit the aforementioned criteria are shown in Table 1 and Fig. 2.
Although there are three types of municipalities, the present study uses the term "town" to represent all small cities, towns and subdistricts in this study for purposes of consistency. Moreover, the use of the term "city" may overlap with the term "province". Thus, the term "town" is used throughout this paper. To assess these ten towns, this study collected data from the residents because, among place customers, residents are arguably the most valuable group of stakeholders (Kavaratzis 2012; Merrilees et al. 2012). If the mayor of a town can successfully assess and manage residents' perceptions, then the potential exists to make the place more attractive and sustainable (Braun et al. 2013; Insch and Florek 2008; Taecharungroj 2016). Mayors or place brand managers who do not assess residents' perceptions in the place branding and management processes risk losing their understanding of the place (Aitken and Campelo 2011). The authors used a cluster random sampling method to collect data from the residents through pen-and-paper questionnaire surveys in the Thai language. Surveys were collected at community locations in those towns from August to October 2018. The questionnaire first requested general information from respondents such as age, sex, education level and income level. The second section consisted of questions that measure residents' perceptions of the sustainability of the ten towns using 36 7-point Likert-scale items rated from (1) Strongly Disagree to (7) Strongly Agree. The scale was developed by Taecharungroj et al. (2018) to measure place sustainability of a town in Thailand. Therefore, it is compatible with this current research. Those 36 items were used to assess the performance of the 11 sustainability dimensions. The list of items is shown in Table 8 (Appendix). In total, 2157 completed questionnaires were useable. Table 2 shows the demographics of the respondents.

The level of importance of each place sustainability dimension was calculated using an implicit derived measure. The implicit importance, also called the statistically inferred method, was used to avoid the biases that often come with methods directly measuring importance (Azzopardi and Nash 2013). Using this method, the level of importance is
Table 1 Ten towns/ municipalities: type, province and level of density

\begin{tabular}{llll}
\hline Town/municipality & Type of municipality & Province & Density \\
\hline Samut Prakan (SP) & City municipality & Samut Prakan & High \\
Samut Sakhon (SS) & City municipality & Samut Sakhon & Upper middle \\
Khu Khot (KK) & Town municipality & Pathum Thani & Upper middle \\
Bang Sri Muang (BS) & Town municipality & Nonthaburi & High \\
Sampran (SM) & Town municipality & Nakhon Pathom & Lower middle \\
Thanyaburi (TY) & Subdistrict municipality & Pathum Thani & Lower middle \\
Bang Bo (BB) & Subdistrict municipality & Samut Prakan & Lower middle \\
Bang Moung (BM) & Subdistrict municipality & Nonthaburi & Upper middle \\
Ban Pho (BP) & Subdistrict municipality & Chachoengsao & Low \\
Salaya (SL) & Subdistrict municipality & Nakhon Pathom & Low \\
\hline
\end{tabular}




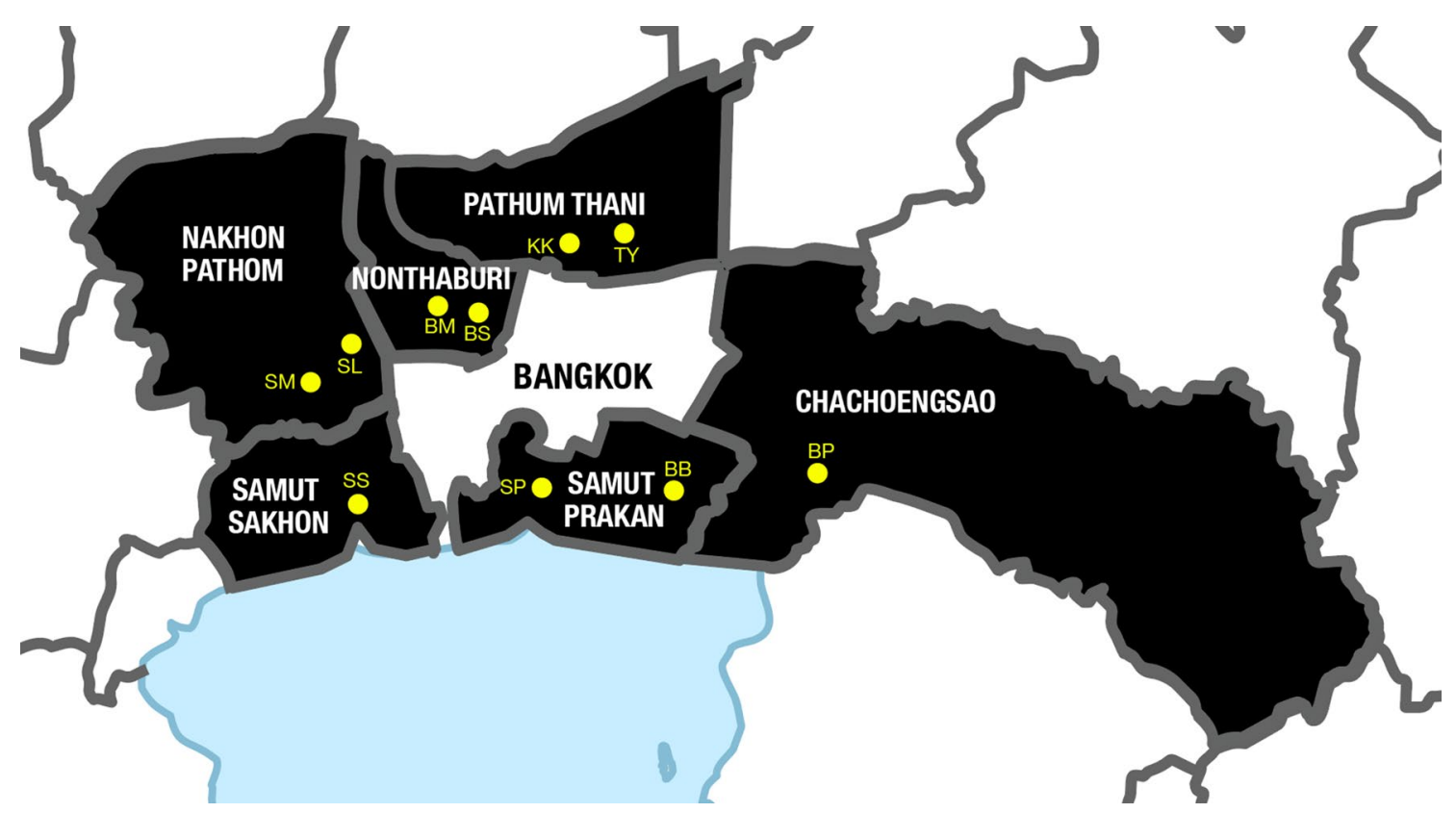

Fig. 2 The ten towns in the six provinces in the Vicinity of Bangkok. (source: https://commons.wikimedia.org/wiki/File:Thailand_adm_locat ion_map.svg)

Table 2 Demographics of respondents

\begin{tabular}{|c|c|c|c|c|c|}
\hline & $\mathrm{n}$ & $\%$ & & $\mathrm{n}$ & $\%$ \\
\hline Sex & & & House & & \\
\hline Male & 839 & 38.9 & Detached & 1022 & 47.4 \\
\hline Female & 1318 & 61.1 & Condo & 88 & 4.1 \\
\hline Workplace & & & Commercial building & 239 & 11.1 \\
\hline In this town & 1479 & 68.6 & Town house & 390 & 18.1 \\
\hline Outside of town & 676 & 31.4 & Flat/apartment/dorm & 380 & 17.6 \\
\hline Missing & 2 & 0.1 & Others & 38 & 1.8 \\
\hline Age & & & Education & & \\
\hline$<18$ & 252 & 11.7 & Lower than secondary & 206 & 9.6 \\
\hline $18-24$ & 462 & 21.4 & Secondary school & 313 & 14.5 \\
\hline $25-34$ & 552 & 25.6 & High school & 476 & 22.1 \\
\hline $35-44$ & 411 & 19.1 & Vocational & 476 & 22.1 \\
\hline $45-54$ & 285 & 13.2 & Undergraduate & 606 & 28.1 \\
\hline $55-64$ & 155 & 7.2 & Postgraduate & 79 & 3.7 \\
\hline$>64$ & 40 & 1.9 & Missing & 1 & 0 \\
\hline Occupation & & & Income & & \\
\hline Students & 431 & 20 & $<5 \mathrm{k}$ & 129 & 6 \\
\hline Business & 604 & 29 & $5-10 \mathrm{k}$ & 374 & 17.3 \\
\hline Service & 263 & 12.5 & 10-20k & 890 & 41.3 \\
\hline Employee (private) & 503 & 24.4 & 20-30k & 378 & 17.5 \\
\hline Employee (public) & 89 & 4.2 & $30-40 \mathrm{k}$ & 106 & 4.9 \\
\hline Civil servant & 122 & 5.7 & $>40 \mathrm{k}$ & 66 & 3.1 \\
\hline Farmer (rice) & 4 & 0.2 & No income & 212 & 9.8 \\
\hline Farmer (other crops) & 22 & 1 & Missing & 2 & 0.1 \\
\hline Unemployed/housework/retired & 59 & 2.7 & & & \\
\hline Others & 5 & 0.3 & & & \\
\hline Total & 2157 & 100 & Total & 2157 & 100 \\
\hline
\end{tabular}


derived from the standardised coefficients or correlations between each dimension and the single desired outcome (Azzopardi and Nash 2013; Matzler et al. 2003). In this case, the single desired outcome is the composite variable of city citizenship and city ambassadorship behaviours (Taecharungroj 2016). Ambassadorship behaviours are the behaviours of residents who advocate for the city through positive wordof-mouth communications and recommendations (Braun et al. 2013; Fullerton 2003; Taecharungroj 2016). City citizenship behaviours were adapted from organisation citizenship behaviours (OCB), which refer to the positive, helpful and desirable behaviours of the members of the organisation (Nadiri and Tanova 2010; Organ 1988; Podsakoff et al. 2000). In the context of place management, city citizenship behaviours are the behaviours of residents who "contribute to the city by helping other people and participating in events that can improve the city" (Taecharungroj 2016). These two behaviours were measured using four 7-point Likert scale items. City citizenship and city ambassadorship behaviours are two types of behaviours that could grow the city by attracting new visitors and residents (Taecharungroj 2016). Therefore, it is a good measure for the important assessment because apart from being credible, a good brand position for a place must drive growth. The authors used a multiple linear regression method to determine the levels of importance using IBM's SPSS version 21.

\section{Findings}

From a total of 2157 useable questionnaire surveys, descriptive statistics and correlations of variables are presented in Table 3 . The sustainability dimension that has the highest mean score is economic growth, at 4.54 out of 7; conversely, water and waste management has the lowest score, at 3.72 .
The reliability test shows that the Cronbach's alphas range from 0.79 to 0.92 , implying good reliability. The dependent variable, ambassadorship and citizenship behaviours, was measured using four items; they also demonstrated good reliability (Cronbach's alpha $=0.82$ ). Table 3 also shows the correlations among dimensions in the study using Pearson's correlation coefficients. All correlation scores are less than 0.80 indicating no multicollinearity concern. The average scores presented in Table 3 were used to indicate the level of performance in SPBA.

To determine the level of importance, a multiple regression analysis was tested using ambassadorship and citizenship behaviour as the dependent variable and place sustainability dimensions as independent variables. A significant regression equation was found $(F(11,2145)=107.34$, $p<0.001$ ), with an $R^{2}$ of 0.36 . An enter method was used, finding that 7 sustainability dimensions, natural environment, social equity, economic growth, built environment, landscape, liveability and energy, explain a significant amount of the variance in ambassadorship and citizenship behaviours (Table 4). The standardised coefficient (beta) between each place sustainability dimension and the dependent variable was used to determine the level of importance. As shown by the results in Table 4, natural environment has the highest positive standardised coefficient; conversely, conviviality has the highest negative level.

An analysis of SPBA was conducted using the importance and performance data. The authors adopted a datacentred approach (Azzopardi and Nash 2013); the average scores of perceived quality (performance) and importance were used to set the grid intersection. Figure 3 illustrates the position of each place sustainability dimension in the chart. Three were located in the "brand" (top-right) section, meaning that they have, on average, both high performance and high importance. Those three dimensions include economic

Table 3 Dimension correlation, mean score, standard deviation and Cronbach's alpha matrix

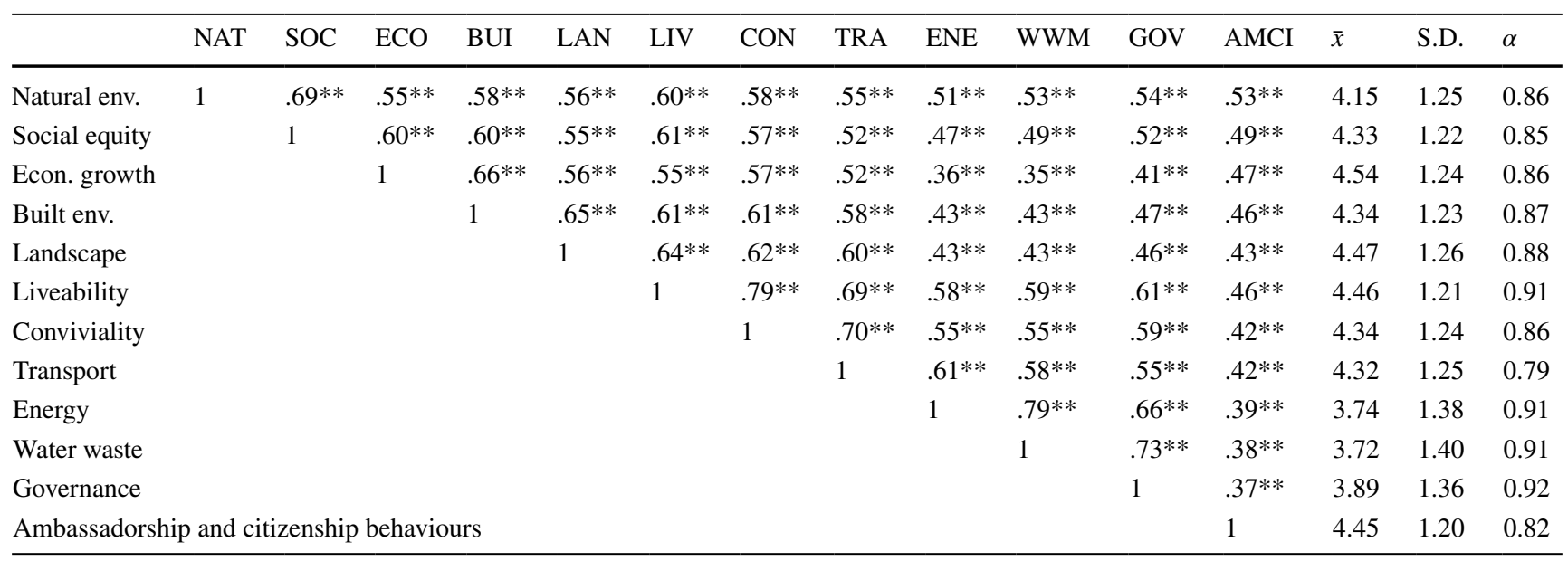

***Correlation is significant at the 0.01 level (2-tailed) 
Table 4 Multiple regression with ambassadorship and citizenship behaviours as the dependent variable

\begin{tabular}{|c|c|c|c|c|c|}
\hline & \multicolumn{2}{|c|}{$\begin{array}{l}\text { Unstandardised } \\
\text { coefficients }\end{array}$} & \multirow{2}{*}{$\begin{array}{l}\text { Standard- } \\
\text { ised coef- } \\
\text { ficients } \\
\text { Beta }\end{array}$} & \multirow[t]{2}{*}{$t$} & \multirow[t]{2}{*}{ Sig. } \\
\hline & $B$ & Std. error & & & \\
\hline (Constant) & 1.427 & 0.095 & & 15.077 & 0.000 \\
\hline $\begin{array}{l}\text { Natural environ- } \\
\text { ment }\end{array}$ & 0.237 & 0.026 & 0.247 & 9.208 & 0.000 \\
\hline Social equity & 0.086 & 0.027 & 0.087 & 3.207 & 0.001 \\
\hline $\begin{array}{l}\text { Economic } \\
\text { growth }\end{array}$ & 0.165 & 0.025 & 0.170 & 6.733 & 0.000 \\
\hline $\begin{array}{l}\text { Built environ- } \\
\text { ment }\end{array}$ & 0.060 & 0.027 & 0.062 & 2.266 & 0.024 \\
\hline Landscape & 0.057 & 0.025 & 0.059 & 2.279 & 0.023 \\
\hline Liveability & 0.070 & 0.032 & 0.070 & 2.173 & 0.030 \\
\hline Conviviality & -0.047 & 0.030 & -0.048 & -1.551 & 0.121 \\
\hline Transport & 0.009 & 0.027 & 0.009 & 0.316 & 0.752 \\
\hline Energy & 0.070 & 0.026 & 0.081 & 2.706 & 0.007 \\
\hline Water waste & 0.037 & 0.028 & 0.043 & 1.327 & 0.185 \\
\hline Governance & -0.037 & 0.024 & -0.041 & -1.497 & 0.135 \\
\hline
\end{tabular}

growth, liveability and health and social equity. Conviviality, landscape, transport and built environment are the four dimensions in the "educate" (bottom-right) section, meaning that although the performance is high, it is, on average, less important from the perspective of residents. Four other dimensions that have below-average performance are in the "improve" (left) section of the chart, including natural environment, energy, water and waste management and governance. In particular, although natural environment has low performance, it has the highest level of importance. It is imperative for towns to focus on the improvement of this dimension.

Apart from the overall analysis, the authors analysed each town separately to determine appropriate suggestions for each town according to SPBA. Table 5 shows the levels of performance of each dimension of place sustainability towns. Across all dimensions, Bang Moung has the highest level of perceived performance by the residents ( 4.77 out of 7), followed by Salaya (4.50) and Samut Prakan (4.37). The residents of Bang Moung have favourable perceptions of their town; Bang Moung has the highest scores in seven dimensions of place sustainability, except for economic growth, built environment, landscape and transport, in which Salaya is higher. Conversely, Khu Khot has the lowest performance (3.71), followed by Thanyaburi (3.94) and Bang Bo (4.00). Khu Khot, in particular, scores the lowest in eight out of eleven dimensions.

The levels of importance of each dimension are implied by the relationships between dimensions of place sustainability and ambassadorship and citizenship as a result of multiple regression analyses (Table 6). The average levels of importance for each town range from 0.05 to 0.08 . The results show that residents of each town hold dimensions at different levels of implied importance. For example, there is a significant relationship between the natural environment and desirable behaviours in Samut Prakan, Samut Sakhon, Khu Khot, Bang Bo and Ban Pho. In contrast, the relationships are nonsignificant in other towns. There are also some negative relationships. For example, liveability and health have a strong positive relationship with desirable behaviours $\left(0.48^{* *}\right)$ in Bang Moung, whereas the relationships are significantly negative in Samut Sakhon $\left(-0.27^{*}\right)$ and Khu Khot $\left(-0.37^{*}\right)$. Of the eleven dimensions, transport and water and waste management show no significant relationship

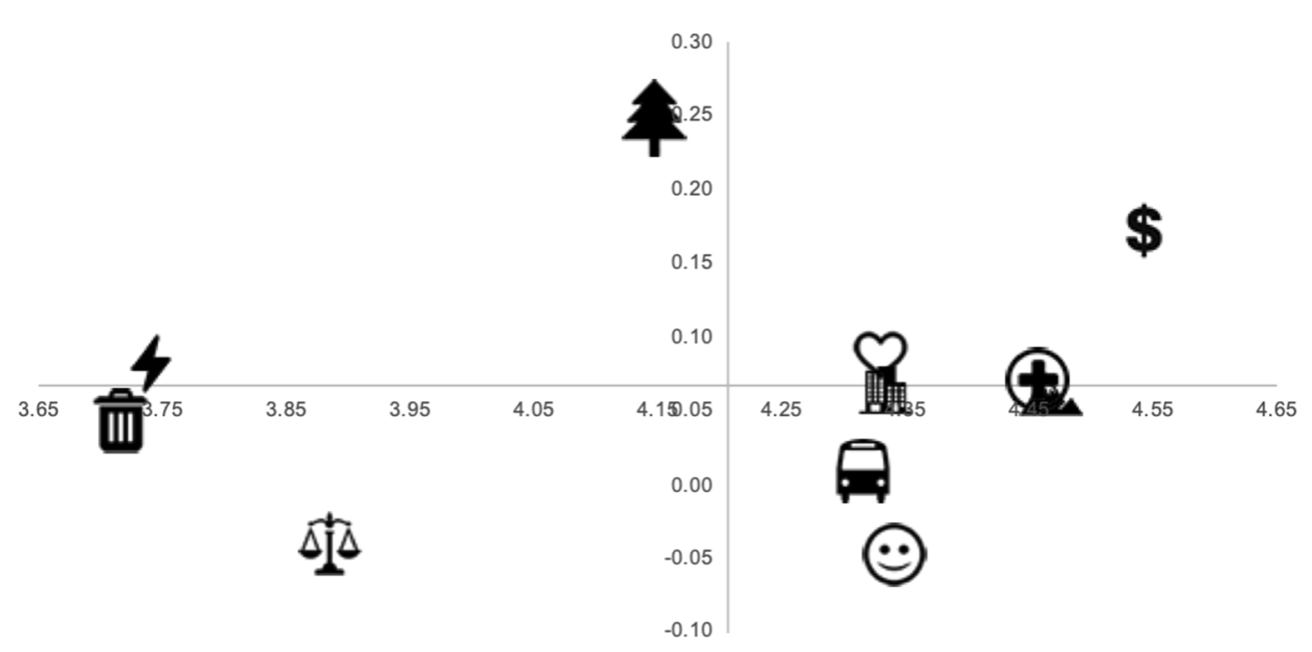

\begin{tabular}{|c|c|}
\hline & Natural environment \\
\hline & Social equity \\
\hline $\boldsymbol{\Psi}$ & Economic growth \\
\hline 䀦用 & Built environment \\
\hline & Landscape \\
\hline (4) & Liveability \& health \\
\hline$\odot$ & Conviviality \\
\hline ه & Transport \\
\hline 7 & Energy \\
\hline IIII & Water \& waste mgmt. \\
\hline$\widehat{\Delta \Pi^{\Delta} \Delta}$ & Governance \\
\hline
\end{tabular}

Fig. 3 The sustainable place branding analysis for ten towns in the Vicinity of Bangkok 
Table 5 Levels of performance of each dimension of place sustainability by towns

\begin{tabular}{lcccccccccccc}
\hline City/town & NAT & SOC & ECN & BUI & LAN & LIV & CON & TRA & ENE & WWM & GOV & $\bar{x}$ \\
\hline Samut Prakan & 4.19 & 4.33 & 4.64 & 4.46 & 4.68 & 4.56 & 4.45 & 4.71 & 4.02 & 4.04 & 3.98 & 4.37 \\
Samut Sakhon & 4.04 & 4.28 & 4.79 & 4.50 & 4.48 & 4.44 & 4.45 & 4.12 & 3.42 & 3.43 & 4.08 & 4.18 \\
Khu Khot & 3.65 & 4.04 & 4.25 & 3.95 & 3.81 & 4.08 & 4.03 & 3.77 & 2.93 & 2.92 & 3.39 & 3.71 \\
Bang Sri Muang & 4.26 & 4.29 & 4.07 & 3.92 & 4.58 & 4.55 & 4.27 & 4.28 & 4.19 & 4.13 & 4.01 & 4.23 \\
Sampran & 4.27 & 4.42 & 4.54 & 4.41 & 4.50 & 4.39 & 4.35 & 4.44 & 4.08 & 4.06 & 4.06 & 4.32 \\
Thanyaburi & 3.98 & 4.14 & 4.40 & 4.18 & 4.54 & 4.11 & 4.02 & 3.99 & 3.09 & 3.04 & 3.84 & 3.94 \\
Bang Bo & 3.95 & 4.06 & 4.46 & 4.18 & 4.26 & 4.12 & 4.07 & 4.10 & 3.54 & 3.66 & 3.64 & 4.00 \\
Bang Moung & 4.76 & 4.93 & 4.82 & 4.59 & 4.42 & 5.40 & 4.87 & 4.75 & 4.72 & 4.71 & 4.55 & 4.77 \\
Ban Pho & 4.17 & 4.36 & 4.59 & 4.37 & 4.50 & 4.35 & 4.33 & 4.24 & 3.41 & 3.42 & 3.58 & 4.12 \\
Salaya & 4.26 & 4.55 & 4.90 & 4.85 & 5.03 & 4.61 & 4.67 & 4.83 & 4.08 & 3.84 & 3.81 & 4.50 \\
$\bar{x}$ & 4.15 & 4.34 & 4.55 & 4.34 & 4.48 & 4.46 & 4.35 & 4.32 & 3.75 & 3.72 & 3.89 &
\end{tabular}

NAT natural environment, SOC social equity, ECN economic growth, BUI built environment, LAN landscape, LIV liveability and health, CON conviviality, TRA transport, ENE energy, WWM water and waste management, GOV governance

Table 6 Levels of importance of each dimension of place sustainability by towns

\begin{tabular}{|c|c|c|c|c|c|c|c|c|c|c|c|c|}
\hline City/town & NAT & SOC & ECN & BUI & LAN & LIV & $\mathrm{CON}$ & TRA & ENE & WWM & GOV & $\overline{\mathrm{x}}$ \\
\hline Samut Prakan & $0.27 *$ & 0.09 & $0.27 *$ & -0.07 & $0.22 *$ & 0.00 & 0.03 & 0.04 & -0.06 & -0.19 & 0.09 & 0.06 \\
\hline Samut Sakhon & $0.41 * *$ & -0.13 & $0.37 * *$ & 0.08 & -0.02 & $-0.27^{*}$ & $0.23 *$ & 0.00 & $0.22 *$ & -0.04 & $-0.18 *$ & 0.06 \\
\hline Khu Khot & $0.18^{*}$ & $0.22 *$ & 0.07 & 0.15 & 0.08 & $-0.37 *$ & 0.00 & 0.08 & -0.12 & 0.03 & $0.32 *$ & 0.06 \\
\hline Bang Sri Muang & 0.08 & 0.13 & 0.06 & 0.09 & $0.20 *$ & 0.10 & 0.10 & -0.08 & -0.06 & 0.08 & $0.24 * *$ & 0.08 \\
\hline Sampran & 0.07 & -0.05 & $0.25 * *$ & $0.27 *$ & $0.27 *$ & 0.14 & -0.05 & -0.06 & 0.05 & -0.18 & 0.03 & 0.07 \\
\hline Thanyaburi & 0.04 & 0.03 & $0.17 *$ & 0.13 & 0.18 & -0.02 & -0.18 & -0.06 & 0.10 & 0.20 & 0.00 & 0.05 \\
\hline Bang Bo & $0.23 *$ & $0.28 *$ & 0.14 & -0.15 & 0.20 & 0.21 & $0.09 *$ & -0.06 & 0.07 & -0.15 & -0.22 & 0.06 \\
\hline Bang Moung & 0.02 & 0.01 & 0.03 & 0.12 & -0.05 & $0.48 * *$ & -0.07 & -0.01 & 0.10 & 0.06 & 0.11 & 0.07 \\
\hline Ban Pho & $0.34 * *$ & 0.07 & 0.06 & $0.21 *$ & -0.02 & 0.20 & -0.06 & 0.03 & 0.01 & 0.05 & -0.06 & 0.07 \\
\hline Salaya & 0.15 & $0.29 * *$ & 0.13 & 0.04 & 0.12 & 0.02 & 0.07 & 0.08 & 0.01 & -0.07 & 0.10 & 0.08 \\
\hline$\overline{\mathrm{x}}$ & 0.18 & 0.09 & 0.16 & 0.09 & 0.12 & 0.05 & 0.02 & 0.00 & 0.03 & -0.02 & 0.04 & \\
\hline
\end{tabular}

NAT natural environment, $S O C$ social equity, $E C N$ economic growth, BUI built environment, $L A N$ landscape, $L I V$ liveability and health, $C O N$ conviviality, TRA transport, ENE energy, $W W M$ water and waste management, $G O V$ governance

$*$ p value $>0.05 ; * *$ p value $>0.001$

with desirable behaviours in any of the towns. Residents may not perceive transport and water and waste management as important dimensions that lead to desirable behaviours.

The data from residents suggest that although there is a general pattern, as shown in Fig. 5, each town should take different actions. As shown by the SPBA analysis (Table 7 and Figs. 4, 5, 6, 7, 8, 9, 10, 11, 12, 13 in the Appendix), the number of dimensions of place sustainability that should be used as a brand position vary from one (Bang Moung) to five (Khu Khot). Table 7 summarises all the dimensions of place sustainability of each town into three suggested actions. Icons were ordered based on the level of importance. Some of the results are congruent with the overall results; economic growth is the most common dimension in the brand section (7 towns). Transport and conviviality fall within the educate section of 7 towns, which emulate the overall results. Most towns in the vicinity of Bangkok need to emphasise informing residents of the importance of sustainable modes of transport and place conviviality. The most congruent findings are the dimensions in the improve section; energy, waste and water management and governance are in the improve section of every town. However, some findings from individual analysis differ from the overall results. For example, landscape is present in the brand section of 7 towns, although its level of importance is not high in the overall results. Social equity and liveability and health are both present in the brand section in the overall result, but they are the branding dimensions for only 4 and 5 towns, respectively. These results imply the differences between individual analysis and the overall results. In conclusion, it is essential for each place to analyse and determine its own place brand position. 
Table 7 Suggested actions for ten towns

\begin{tabular}{|c|c|c|c|c|}
\hline Town & $\mathbf{n}$ & Brand & Educate & Improve \\
\hline Samut Prakan & 202 & $\$ \AA$ & $9 \oplus \oplus$ 䁌 & 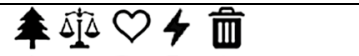 \\
\hline Samut Sakhon & 223 & $\mathbf{\$} \odot$ 踻 & $\therefore \varnothing \oplus$ & 4日而能 \\
\hline Khu Khot & 206 & ○助国今 & $\oplus \oplus$ & 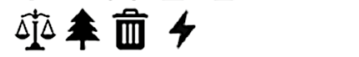 \\
\hline Bang Sri Muang & 220 & $\Delta \nabla \odot \oplus$ & 里 & 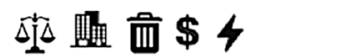 \\
\hline Sampran & 214 & 融会\$ & 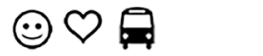 & 4 祉血 \\
\hline Thanyaburi & 205 & 今 \$ 踇 & $40 \oplus \theta$ & 而 4 䀡 \\
\hline Bang Bo & 227 & $\varnothing \oplus \Delta \$$ & 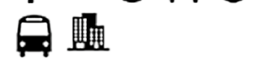 & 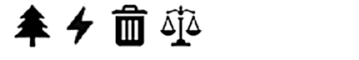 \\
\hline Bang Moung & 220 & $\oplus$ & $\$ 0 \odot$ & 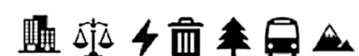 \\
\hline Ban Pho & 230 & 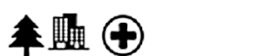 & ○\$A $-;$ & 血 4 斾 \\
\hline Salaya & 210 & $0 \$$ & 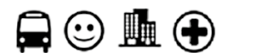 & 年鸰 4 而 \\
\hline
\end{tabular}

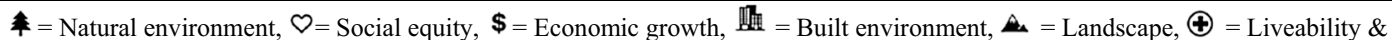

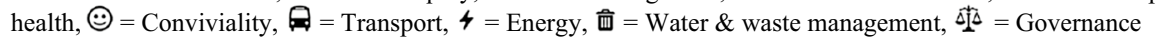

Fig. 4 Samut Prakan's SPBA

Fig. 5 Samut Sakhon's SPBA

\section{SAMUT PRAKAN}

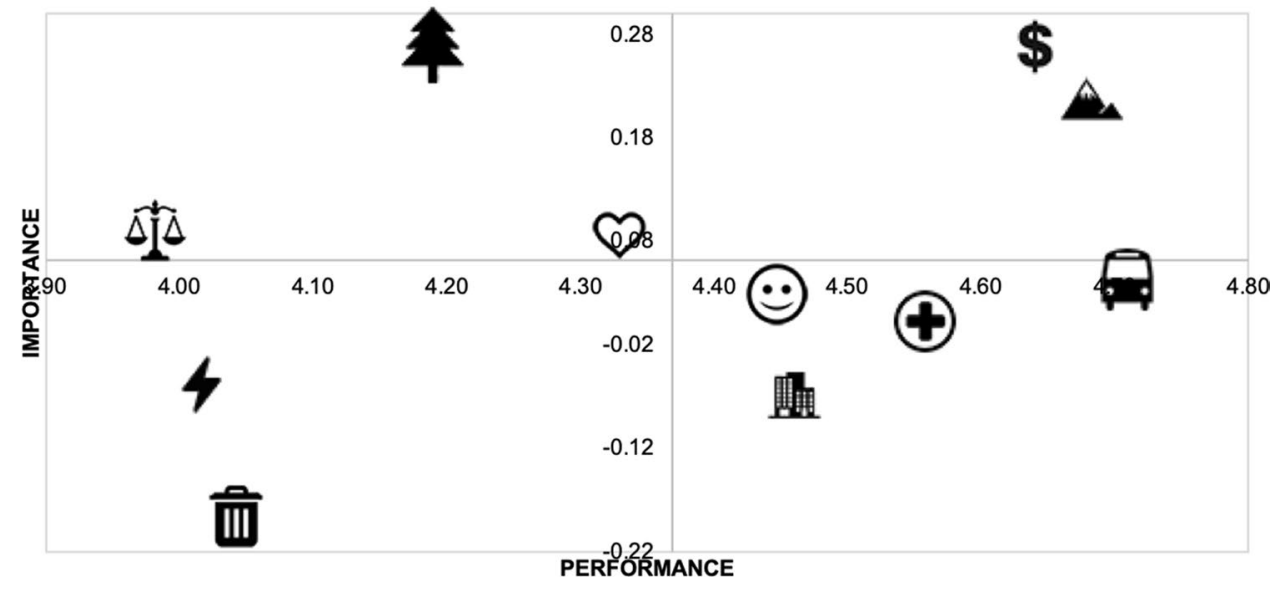

PERFORMANCE

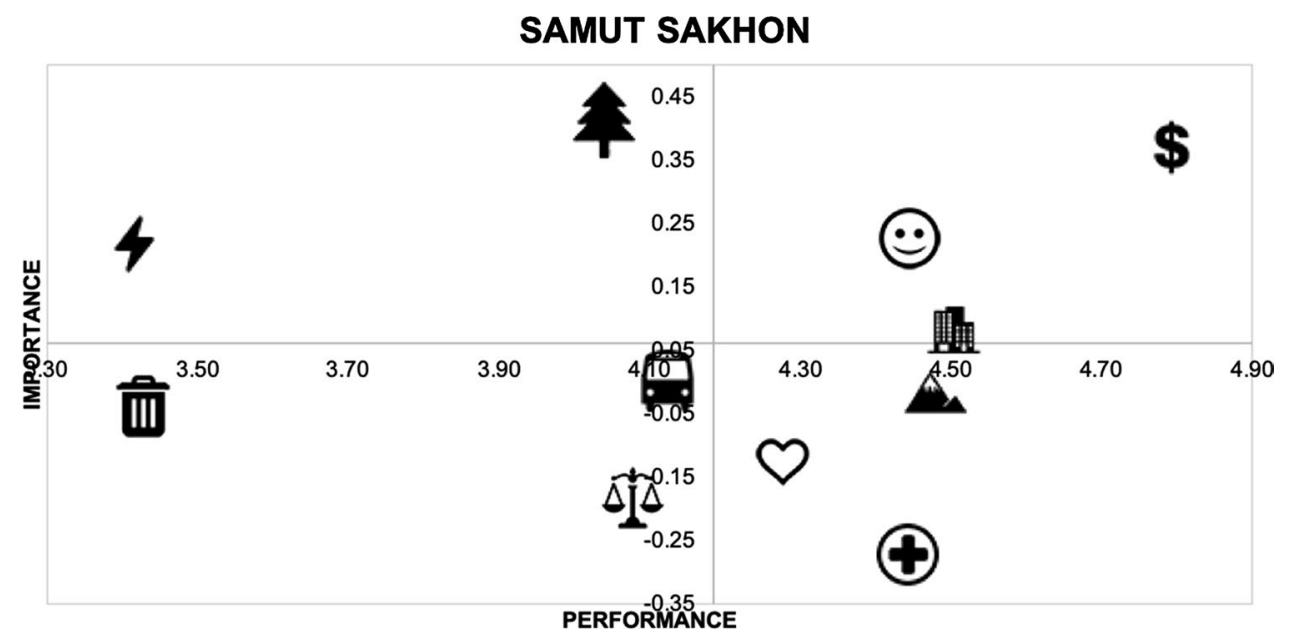


Fig. 6 Khu Khot's SPBA

Fig. 7 Bang Sri Muang's SPBA

Fig. 8 Sampran's SPBA

BANG SRI MUANG

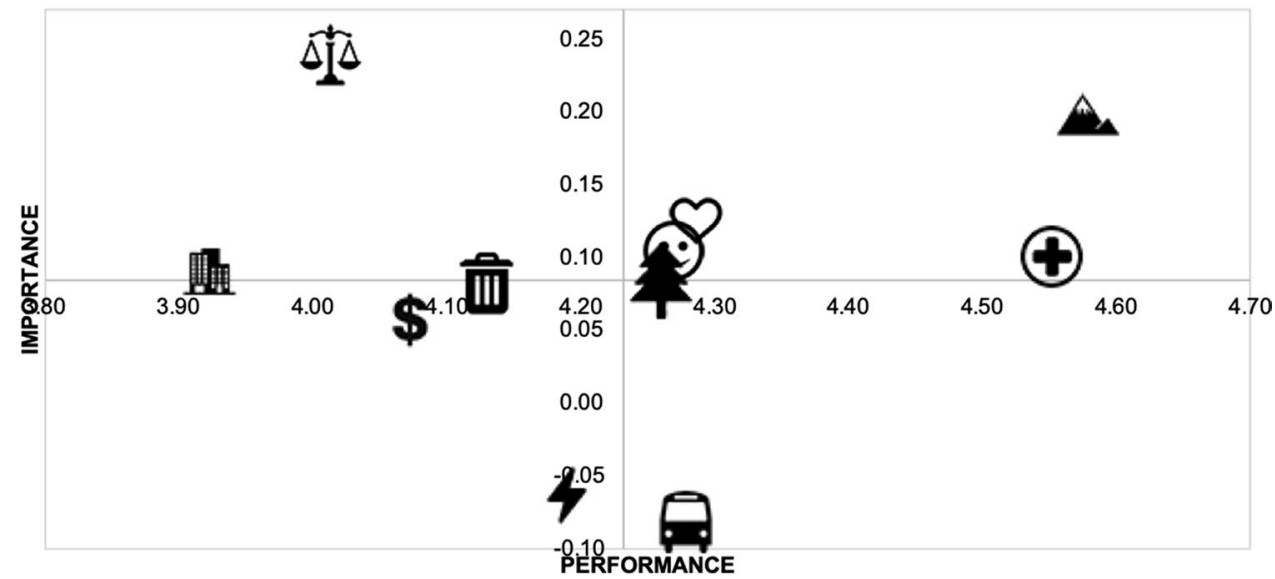

SAMPRAN
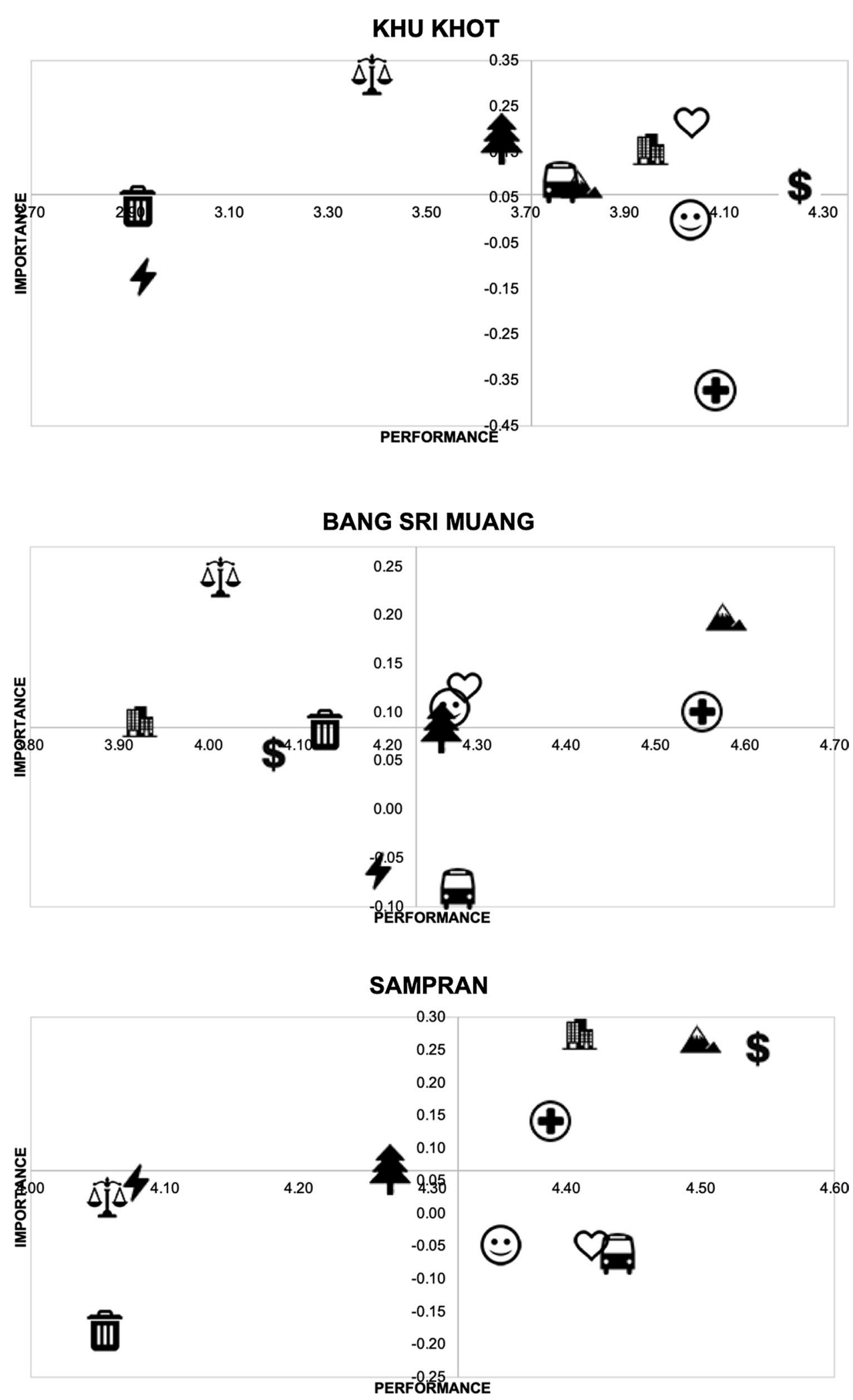
Fig. 9 Thanyaburi's SPBA

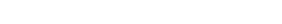

Fig. 10 Bang Bo's SPBA

Fig. 11 Bang Moung's SPBA

\section{THANYABURI}

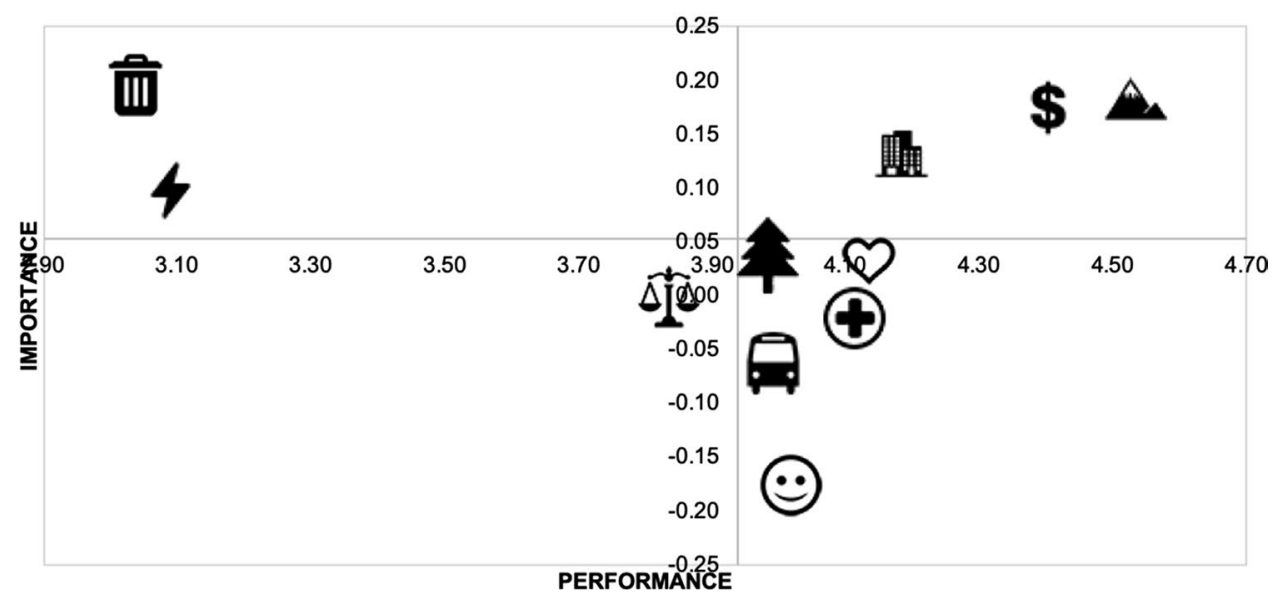

\section{BANG BO}

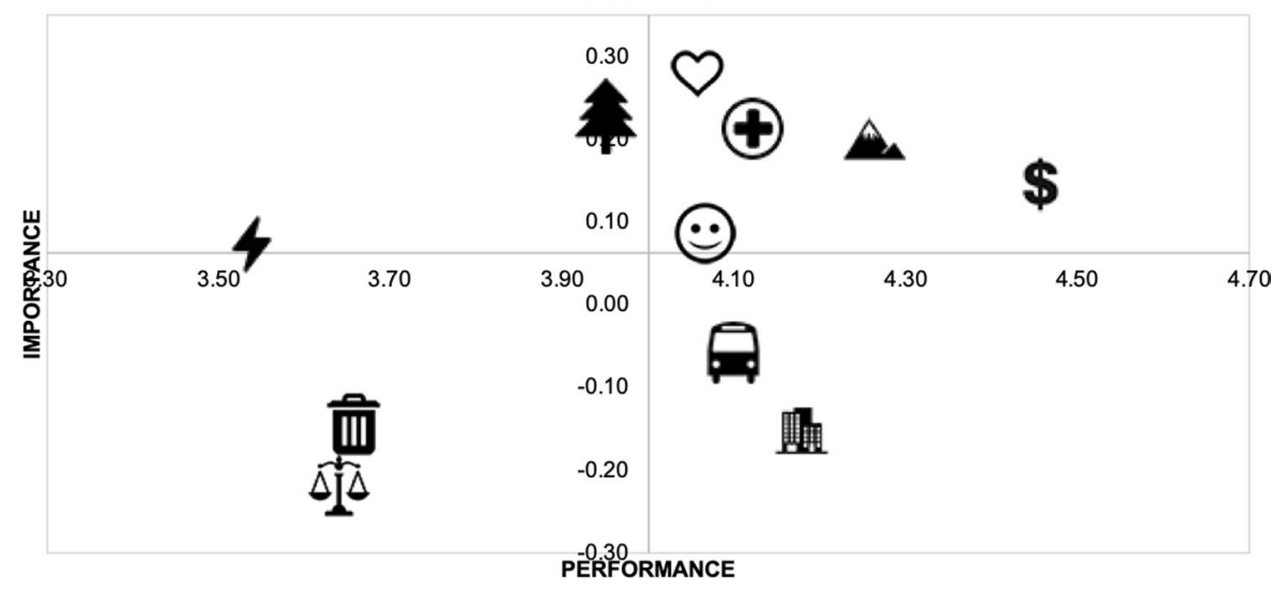

BANG MOUNG

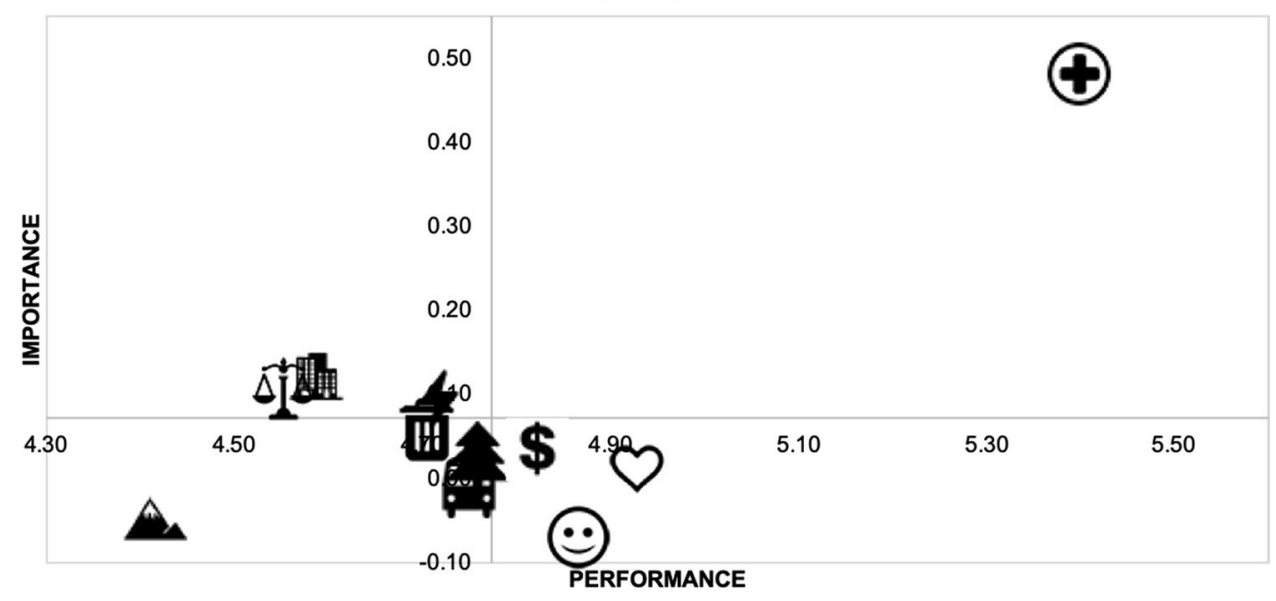

\section{Discussions and conclusion}

The purpose of this study was to develop a practical tool that could help mayors of small towns with limited resources that face sustainability challenges to assess and formulate an appropriate brand position. SPBA is a tool that was adapted from the IPA in order to address such place branding challenges. SPBA of ten towns in Bangkok's vicinity was developed using data obtained from their residents. The results in Table 5 demonstrate that residents have differing levels 
Fig. 12 Ban Pho's SPBA

BAN PHO

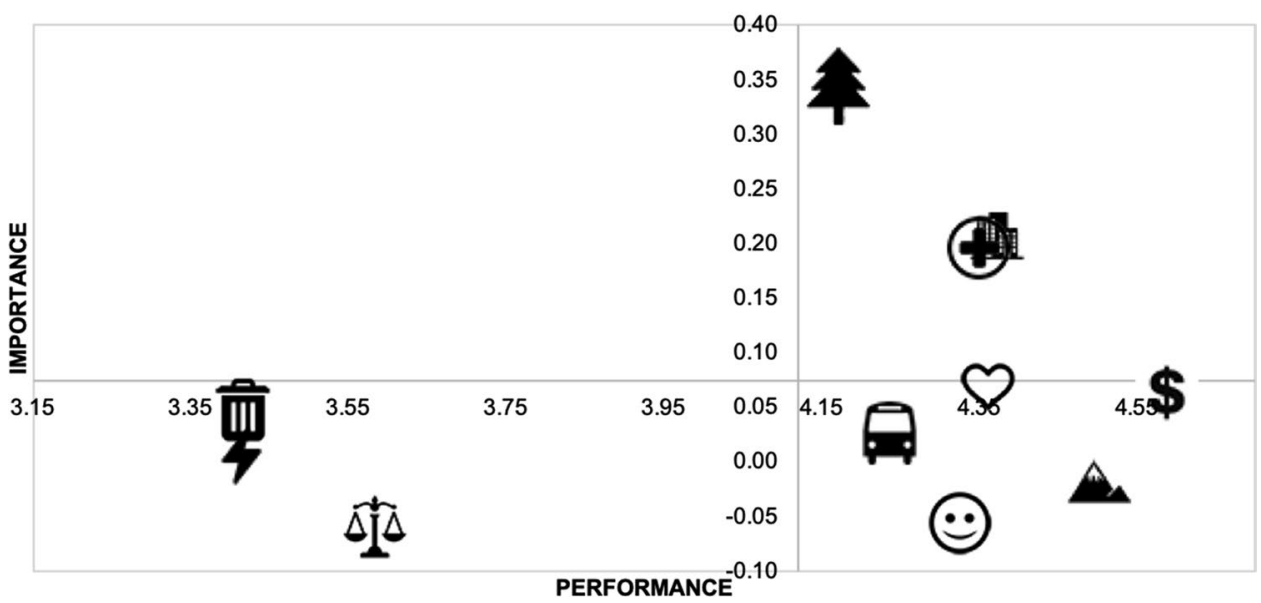

Fig. 13 Salaya's SPBA

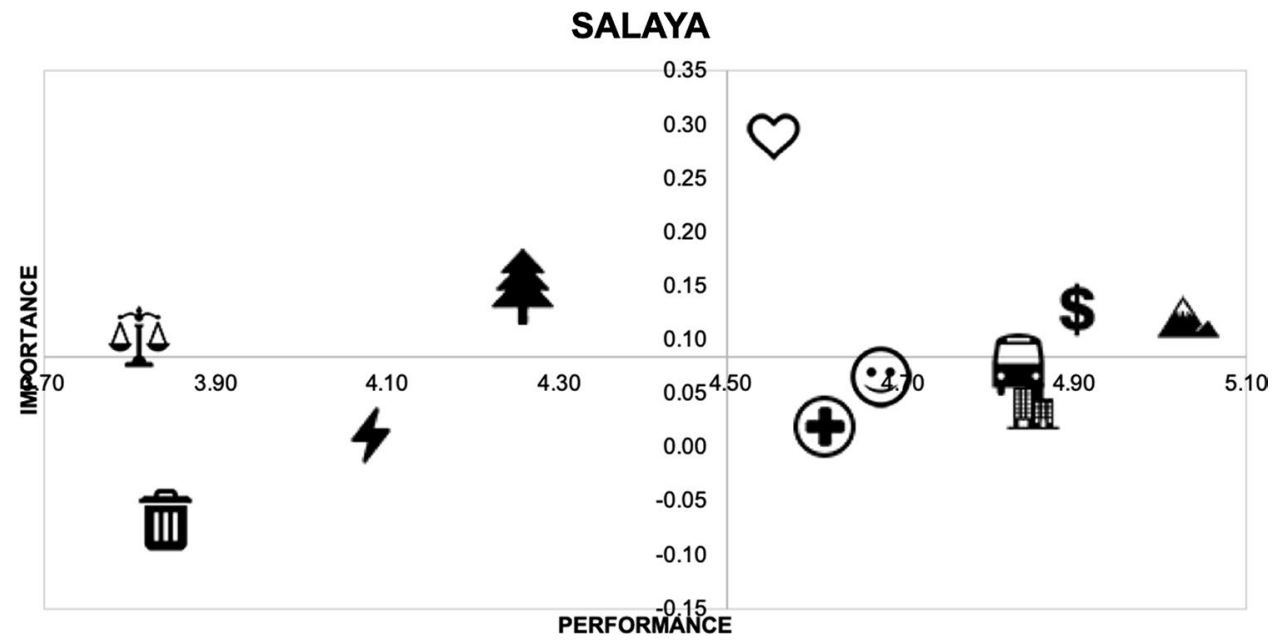

of perceptions regarding sustainability dimensions. For example, the levels of performance of natural environment in seven out of ten towns are below average (fall into the "improve" section of SPBA). A blanket adoption of natural environment as a brand position might not be ideal for every town (Zavattaro 2014) because it might not resonate with the perceptions of residents. The other axis of analysis is the implied importance of each dimension, or the strength of relationships between those dimensions and the desired behaviours of the residents. Like performance, the levels of importance of each dimension of place sustainability are not homogeneous among towns. Some dimensions significantly and positively affect the desired behaviours in certain towns but not in others. The investigation into the relationship between implied importance and attitudes and behaviours of residents is not within the scope of this study. Nevertheless, some surprising and contrasting results, such as the negative relationships between liveability and health and desired behaviours in two towns, suggest that further study is required to understand how and why sustainability affects residents' attitudes and behaviours differently.
The research question focuses on the dimensions that fall within the brand section of SPBA because they can be used as a basis of a place brand position. A further analysis of those dimensions helps us detect certain patterns that can be used by mayors to brand their towns. The authors analysed the findings in Tables 5, 6, 7 and grouped the ten towns into five types of sustainable towns based on the dimensions that fall within the brand section of SPBA. The five types of sustainable town were formulated based on the authors' interpretation of the results; cluster analysis was not used because the number of towns, 10 , is too low to group them statistically.

- Elegant town (Samut Prakan, Sampran, Thanyaburi): An elegant town is characterised by high levels of performance and importance in economic growth and landscape. Elegant towns have high quality and capacity of economic infrastructure, economic diversity and comparative advantage. Furthermore, they are aesthetically pleasing; the buildings and physical infrastructure are accessible, appropriate and beautiful. Mayors can utilise these outstanding qualities to brand these towns. Examples of places in 
Bangkok's vicinity that should use this brand position are Samut Prakan, Sampran and Thanyaburi. Samut Prakan and Sampran both have above-average levels of performance of economic growth and landscape, as well as high levels of importance (Tables 5 and 6). In the case of Thanyaburi, although economic growth and landscape are not higher than the average scores among ten towns, they are the two highest dimensions in terms of performance among all sustainability dimensions of Thanyaburi.

- Compassionate town (Salaya, Bang Bo and Khu Khot): A compassionate town has high levels of performance and importance in economic growth and social equity. Although the focus on economic growth is similar to that of the elegant town, compassionate towns emphasise social equity. Apart from economic well-being, compassionate towns improve the quality of life of their lowincome members. Mayors can use the egalitarian nature of the town as a place brand position. Examples of compassionate towns in this research are Salaya, Bang Bo and Khu Khot. All three towns have significant relationships between social equity and residents' desirable behaviours, demonstrating high levels of importance (Table 6).

- Lively town (Samut Sakhon): Similar to elegant and compassionate towns, a lively town has high levels of performance and importance in economic growth. Unlike other types of towns, a lively town has conviviality in its brand section. As such, mayors can emphasise the town's economic growth together with its distinction as a place where residents can gather and enjoy the social and cultural activities in the safe environment. An example of a lively town in this study is Samut Sakhon. Samut Sakhon has significantly higher-than-average levels of performance of economic growth and conviviality (Table 5). Furthermore, those two dimensions have significant relationships, with the desirable behaviours at $0.37^{* *}$ and $0.23^{*}$, respectively (Table 6 ).

- Peaceful town (Bang Moung, Bang Sri Muang): Some towns in the study have exceptional levels of performance and importance in liveability and health. A peaceful town can protect residents from environmental risks, has adequate shelter and medical facilities and promotes the improvement of physical and mental health. Mayors can utilise those characteristics to formulate a brand position for towns that share these features. Examples of peaceful towns in this research are Bang Moung and Bang Sri Muang. Among all towns, Bang Moung has the highest levels of liveability and health in performance (5.40) and importance $\left(0.48^{* *}\right)$. Although the results are not as high as those of Bang Moung, compared with other towns, Bang Sri Muang has above-average levels of performance and importance of liveability and health.

- Green town (Ban Pho): Similar to many examples from the study of Zavattaro (2014), towns can focus on the natural environment quality they possess. In this study, a green town has high levels of performance and importance in natural environment. Among the ten towns in this study, only Ban Pho has natural environment in the brand section of SPBA.

\section{Theoretical contributions}

The findings of this study offer three notable theoretical contributions to place branding and sustainability.

\section{Perception-based typology of sustainable towns}

This study's findings, summarised as elegant, compassionate, lively, peaceful and green towns, complement a body of knowledge on typology of sustainable cities and towns mostly studied by researchers in the fields of urban planning and design. Those researchers analysed cities and towns from various angles, such as the temporal, spatial, physical, economic, developmental and articulated several types and forms of sustainable places. For example, Haughton (1997) studied the interactions between cities and nature and thus identified four types of cities: self-reliant, compact and energy efficient, externally dependent and Fair Share. A seminal paper by Jabareen (2006) summarised the four urban forms, including neotraditional development, compact city, urban containment and ecocity. Jepson and Edwards (2010) indicated three approaches of sustainable urban development including smart growth, new urbanism and ecological city. There have also been a number of discussions about the sustainable and smart city comparison in recent years (Ahvenniemi et al. 2017). These various types of cities and towns help practitioners understand and plan for future development. This current research provides a new angle, a perceptual analysis of residents, to categorise sustainable towns. Compared with other angles of analysis, perceptual analysis is highly relevant to the field of place branding because place branding is the process which focuses on understanding and shaping of stakeholder perceptions (Ashworth 2009; Kavaratzis 2004; Kavaratzis and Ashworth 2005).

\section{Additional benefit of sustainability indicators}

Since the Brundtland Commission published a report for nations to pursue sustainable development (WCED 1987), there has been a proliferation of sustainability indicators (Klopp and Petretta 2017; Krank et al. 2013; Mori and Christodoulou 2012; Pires et al. 2014; Shen and Zhou 2014; Tanguay et al. 2010). Sustainability indicators and indices have been popular in both academia and practices because they provide several benefits to a place, such as giving information, raising awareness, fostering communication, assessing performance, facilitating decision making, demonstrating accountability and benchmarking with other cities (Alberti 1996; Choon et al. 2011; Hiremath et al. 2013; Nieminen and Hyytinen 2015). In addition to those stated benefits, this study used sustainability 
indicators from a study by Taecharungroj et al. (2018) to measure sustainability and thus infer an appropriate place brand position for the ten towns, which could be added to the long list of existing benefits of sustainability indicators.

\section{Sustainable positioning of a place brand}

This study also helps strengthen the link between place branding and sustainability advocated by Govers et al. (2017). A place brand has many essential brand components such as brand identity, brand communications, brand experience and brand engagement (Hanna and Rowley 2011). Existing literature studied the linkages of some brand components and sustainability. For example, Aitken and Campelo (2011) linked engagement with sustainability. Maheshwari et al. (2011) comprehensively investigated the contribution of brand identity, communications, experience, among others to sustainable development. Ryan and Mizerski (2010) explored the connection between various brand components, brand architecture in particular and sustainability. The tool developed in this current research contributes to the place branding and sustainability interface by demonstrating how places can use dimensions of sustainability as a brand position. It offers a way in which towns can analyse and assume the most appropriate sustainable brand position from a wide array of possible positions, which is a challenge of place brand positioning (Hankinson 2010; Insch 2014; Pike 2009).

\section{Managerial implications}

Apart from the three actions that mayors of the ten towns can take according to SPBA analysis, the five types of sustainable towns can be used as a direction to develop and brand these towns. These five types share certain characteristics with many global cities and nations found in previous research. Therefore, these cities can learn from existing successful cases. The elegant town in this research focuses on the quality of landscape as a brand position. Hence, it can learn from the activities and strategies of New Zealand, which fully utilises its natural beauty to promote itself (de San Eugenio Vela et al. 2017). Compassionate towns share an emphasis on social equity, which resonates with the successful case of Bogotá (Kalandides 2011). The lively town can analyse the branding campaigns of Turin (Vanolo 2008) and Raval District in Barcelona (Rius Ulldemolins 2014), both of which have centred their communications on conveying their convivial environment. Mayors of peaceful towns can study the case of a traditional monastic town, New Norcia, in Australia, which employs a traditional lifestyle and healthful products, among others, to brand itself as a sustainable destination (Ryan and Mizerski 2010). Finally, the examples of successful cities that brand themselves as green cities are numerous (Walker 2016; Zavattaro 2014); those examples of campaigns and activities can help green towns manage their place brands effectively. The next steps of the towns are to manage the experience of people in the towns and to communicate the brand position appropriately. Several tools from existing research are available for mayors to use to enhance experience in their towns (Beeho and Prentice 1997; von Friedrichs Grängsjö 2003). Likewise, the communication of the place brand positions should be organised appropriately through different channels both online and offline.

This study's findings point to a number of actions that towns must take to further improve their sustainability. In particular, it is imperative for towns to improve energy, water and waste management and governance because they all have below-average performance. Regarding energy production and consumption, mayors can improve renewable energy usage and consumption using available analytical and strategic planning tools (Terrados, Almonacid, and Hontoria, Terrados 2007) or by encouraging the development of low-energy buildings (Hui 2001). Governance could be improved by adopting a more participatory and democratic process in town planning. For example, towns could organise several meetings among stakeholders to develop a town plan using a participatory backcasting process (Dassen et al. 2013). To foster transparency and collaboration in moving in the new direction, mayors can use several methods, such as informing, consulting, partnering or delegating power to residents and other stakeholders in the town (Arnstein 1969; Virgo and De Chernatony 2006). Improvement of water and waste management also requires strong collaborative actions among the public, private and community sectors (Sukholthaman et al. 2017).

\section{Limitations and future research}

Although the authors developed a practical tool using solid theoretical foundations in this paper, this study is not without limitations. SPBA collected only quantitative data from residents; therefore, the results should not be taken as a definitive answer. Mayors and place brand managers must also consider other research and diagnostic methods to complement SPBA, such as interviews, workshops and observations. SPBA provides only mayors with a snapshot of the residents' perspective at a given time. The perspective of residents might be affected by recent incidents and might also change in the future. It is advisable for mayors to periodically assess residents' perception rather than using a single assessment to guide long-term decisions. Another limitation is the use of multiple regression analysis because many statistical assumptions must be met before conducting the analysis. The results of a multiple regression analysis should be further investigated, especially when the relationship is not significant. Therefore, these results must be interpreted with caution. In this study, the authors grouped ten towns into five types of sustainable towns without a statistical analysis. Future research can collect a sufficient number of towns for the purposes of categorisation using cluster analysis. Furthermore, 
future research should collect data from other towns or cities outside of Thailand to compare results. SPBA can also be used with other levels of places such as neighbourhoods, regions or countries to evaluate the generalisability of the tool.

Acknowledgements The authors thank two brilliant research assistants, Thanamas Singkong and Santanit Uengprapha, the two anonymous reviewers, and the editors, Don Dioko and Robert Govers, for their contribution. The authors also thank Chanathip Pharino and Kitikorn Charmondusit of the Public Well-Being Division of Thailand Research Fund (TRF). This research is funded by TRF (contract no. RDG6130007).
Open Access This article is distributed under the terms of the Creative Commons Attribution 4.0 International License (http://creativeco mmons.org/licenses/by/4.0/), which permits unrestricted use, distribution, and reproduction in any medium, provided you give appropriate credit to the original author(s) and the source, provide a link to the Creative Commons license, and indicate if changes were made.

\section{Appendix}

\section{See Table 8 .}

Table 8 List of dimensions and questionnaire items (Taecharungroj et al. 2018)

\begin{tabular}{|c|c|}
\hline Dimension & Item \\
\hline $\begin{array}{l}\text { Ambassadorship and citizenship } \\
\text { behaviours }\end{array}$ & $\begin{array}{l}\text { You are willing to recommend the town to people (prospective residents, } \\
\text { visitors, businesses) who seek your advice } \\
\text { You would encourage other people (prospective residents, visitors, businesses) } \\
\text { to come to the town } \\
\text { You are ready to attend events that are not required but help the town } \\
\text { You would attend meetings and give opinions that can improve the town }\end{array}$ \\
\hline Natural environment & $\begin{array}{l}\text { Effectively prevents deforestation } \\
\text { Prevents deterioration caused by urban development } \\
\text { Appreciates natural environment }\end{array}$ \\
\hline Social equity & $\begin{array}{l}\text { Improves the conditions of low-income members } \\
\text { Has affordable housing } \\
\text { Promotes social interaction }\end{array}$ \\
\hline Economic growth & $\begin{array}{l}\text { Promotes innovation } \\
\text { Encourages economic clusters } \\
\text { Fosters comparative advantages }\end{array}$ \\
\hline Built environment & $\begin{array}{l}\text { Has a compact built environment } \\
\text { Encourages mixed use of land } \\
\text { Facilitates efficient development }\end{array}$ \\
\hline Landscape & $\begin{array}{l}\text { Has visually appropriate built environment } \\
\text { Has accessible built environment } \\
\text { Has a beautiful landscape }\end{array}$ \\
\hline Liveability and health & $\begin{array}{l}\text { Has a stable environment } \\
\text { Provides adequate shelter } \\
\text { Protects residents from environmental risks } \\
\text { Promotes development of physical and mental health } \\
\text { Has adequate medical facilities and personnel } \\
\text { Promotes disease prevention and treatment programmes }\end{array}$ \\
\hline Conviviality & $\begin{array}{l}\text { Has a safe environment } \\
\text { Offers space for gathering } \\
\text { Promotes cultural and leisure activities }\end{array}$ \\
\hline Transport & $\begin{array}{l}\text { Has good transport connectivity } \\
\text { Has affordable public transport } \\
\text { Has modes of transport that operate on renewable energy }\end{array}$ \\
\hline Energy & $\begin{array}{l}\text { Encourages production of renewable energy } \\
\text { Has sufficient space for renewable energy production } \\
\text { Has passive solar design }\end{array}$ \\
\hline Water and waste management & $\begin{array}{l}\text { Reuses water efficiently } \\
\text { Monitors water quality of water } \\
\text { Encourages waste recycling }\end{array}$ \\
\hline Governance & $\begin{array}{l}\text { Involves residents in the planning process } \\
\text { Involves stakeholders from multiple disciplines } \\
\text { Involves experts in the planning process }\end{array}$ \\
\hline
\end{tabular}




\section{References}

Acharya, A., and Z. Rahman. 2016. Place branding research: A thematic review and future research agenda. International Review on Public and Nonprofit Marketing 13 (3): 289-317.

Ahvenniemi, H., A. Huovila, I. Pinto-Seppä, and M. Airaksinen. 2017. What are the differences between sustainable and smart cities? Cities 60: 234-245.

Aitken, R., and A. Campelo. 2011. The four Rs of place branding. Journal of Marketing Management 27 (9-10): 913-933.

Alberti, M. 1996. Measuring urban sustainability. Environmental Impact Assessment Review 16 (4-6): 381-424.

Andersson, E. 2006. Urban landscapes and sustainable cities. Ecology and Society 11 (1): 34.

Arnstein, S.R. 1969. A ladder of citizen participation. Journal of the American Institute of planners 35 (4): 216-224.

Ashworth, G. 2009. The instruments of place branding: How is it done? European Spatial Research and Policy 16 (1): 9-22.

Azzopardi, E., and R. Nash. 2013. A critical evaluation of importanceperformance analysis. Tourism Management 35: 222-233.

Ball, J. (2017). Germany's high-priced energy revolution. Retrieved from http://fortune.com/2017/03/14/germany-renewable-clean -energy-solar/.

Beeho, A.J., and R.C. Prentice. 1997. Conceptualizing the experiences of heritage tourists: A case study of New Lanark World Heritage Village. Tourism Management 18 (2): 75-87.

Berke, P.R., and M.M. Conroy. 2000. Are we planning for sustainable development? An evaluation of 30 comprehensive plans. Journal of the American Planning Association 66 (1): 21-33.

Braun, E., M. Kavaratzis, and S. Zenker. 2013. My city-my brand: the different roles of residents in place branding. Journal of Place Management and Development 6 (1): 18-28.

Bruff, G.E., and A.P. Wood. 2000. Making sense of sustainable development: Politicians, professionals, and policies in local planning. Environment and Planning C: Government and Policy 18 (5): 593-607.

Camagni, R., R. Capello, and P. Nijkamp. 1998. Towards sustainable city policy: An economy-environment technology nexus. Ecological Economics 24 (1): 103-118.

Campbell, S. 1996. Green cities, growing cities, just cities? Urban planning and the contradictions of sustainable development. Journal of the American Planning Association 62 (3): 296-312.

Chan, C.-S., and L.M. Marafa. 2016. The green branding of Hong Kong: Visitors' and residents' perceptions. Journal of Place Management and Development 9 (3): 289-312.

Chiesura, A. 2004. The role of urban parks for the sustainable city. Landscape and Urban Planning 68 (1): 129-138.

Childers, D.L., S.T. Pickett, J.M. Grove, L. Ogden, and A. Whitmer. 2014. Advancing urban sustainability theory and action: Challenges and opportunities. Landscape and Urban Planning 125: $320-328$

Choon, S.-W., C. Siwar, J.J. Pereira, A.A. Jemain, H.S. Hashim, and A.S. Hadi. 2011. A sustainable city index for Malaysia. International Journal of Sustainable Development \& World Ecology 18 (1): $28-35$.

Dassen, T., E. Kunseler, and L.M. Kessenich. 2013. The sustainable City: An analytical-deliberative approach to assess policy in the context of sustainable urban development. Sustainable Development 21 (3): 193-205.

de San Eugenio Vela, J., J. de San Eugenio Vela, J. Nogué, J. Nogué, R. Govers, and R. Govers. 2017. Visual landscape as a key element of place branding. Journal of Place Management and Development 10 (1): 23-44.

Economist Intelligence Unit. (2016). Global liveability ranking 2016. Retrieved from http://www.eiu.com/public/thankyou_download. aspx?activity=download\&campaignid=Liveability 2016 .
Egger, S. 2006. Determining a sustainable city model. Environmental Modelling \& Software 21 (9): 1235-1246.

Fan, H. 2014. Branding a place through its historical and cultural heritage: The branding project of Tofu Village in China. Place Branding and Public Diplomacy 10 (4): 279-287.

Fuchs, C., and A. Diamantopoulos. 2010. Evaluating the effectiveness of brand-positioning strategies from a consumer perspective. European Journal of Marketing 44 (11/12): 1763-1786.

Fullerton, G. 2003. When does commitment lead to loyalty? Journal of Service Research 5 (4): 333-344.

Govers, R., F. Kaefer, and N. Ferrer-Roca. 2017. The state of academic place branding research according to practitioners. Place Branding and Public Diplomacy 13: 1-3.

Gwin, C.F., and C.R. Gwin. 2003. Product attributes model: A tool for evaluating brand positioning. Journal of Marketing Theory and Practice 11 (2): 30-42.

Hankinson, G. 2010. Place branding research: A cross-disciplinary agenda and the views of practitioners. Place Branding and Public Diplomacy 6 (4): 300-315.

Hanna, S., and J. Rowley. 2011. Towards a strategic place brandmanagement model. Journal of marketing management 27 (5-6): 458-476.

Haughton, G. 1997. Developing sustainable urban development models. Cities 14 (4): 189-195.

Hiremath, R.B., P. Balachandra, B. Kumar, S.S. Bansode, and J. Murali. 2013. Indicator-based urban sustainability-A review. Energy for sustainable development 17 (6): 555-563.

Hui, S.C. 2001. Low energy building design in high density urban cities. Renewable Energy 24 (3): 627-640.

Insch, A. 2014. Positioning cities: Innovative and sustainable strategies for city development and transformation. Place Branding and Public Diplomacy 10 (4): 249-252.

Insch, A., and M. Florek. 2008. A great place to live, work and play: Conceptualising place satisfaction in the case of a city's residents. Journal of Place Management and Development 1 (2): 138-149.

Jabareen, Y.R. 2006. Sustainable urban forms their typologies, models, and concepts. Journal of planning education and research 26 (1): $38-52$.

Jenks, M., and C. Jones. 2009. Dimensions of the sustainable city, vol. 2. Amsterdam: Springer.

Jepson, E.J. 2001. Sustainability and planning: Diverse concepts and close associations. Journal of planning literature 15 (4): 499-510.

Jepson, E.J. 2003. The conceptual integration of planning and sustainability: An investigation of planners in the United States. Environment and Planning C: Government and Policy 21 (3): 389-410.

Jepson, E.J., and M.M. Edwards. 2010. How possible is sustainable urban development? An analysis of planners' perceptions about new urbanism, smart growth and the ecological city. Planning Practice \& Research 25 (4): 417-437.

Kalandides, A. 2011. City marketing for Bogotá: A case study in integrated place branding. Journal of Place Management and Development 4 (3): 282-291.

Kavaratzis, M. 2004. From city marketing to city branding: Towards a theoretical framework for developing city brands. Place Branding 1 (1): 58-73.

Kavaratzis, M. 2012. From "necessary evil" to necessity: Stakeholders' involvement in place branding. Journal of Place Management and Development 5 (1): 7-19.

Kavaratzis, M., and G.J. Ashworth. 2005. City branding: An effective assertion of identity or a transitory marketing trick? Tijdschrift Voor Economische En Sociale Geografie 96 (5): 506-514.

Kenworthy, J.R. 2006. The eco-city: Ten key transport and planning dimensions for sustainable city development. Environment and urbanization 18 (1): 67-85. 
Klopp, J.M., and D.L. Petretta. 2017. The urban sustainable development goal: Indicators, complexity and the politics of measuring cities. Cities 63: 92-97.

Krank, S., H. Wallbaum, and A. Grêt-Regamey. 2013. Perceived contribution of indicator systems to sustainable development in developing countries. Sustainable Development 21 (1): 18-29.

Kunzig, R. (2015). Germany could be a model for how we'll get power in the future. Retrieved from http://www.nationalgeographic.com/ magazine/2015/11/germany-renewable-energy-revolution/.

Lee, H., and D. Jain. 2009. Dubai's brand assessment success and failure in brand management-Part 1. Place Branding and Public Diplomacy 5 (3): 234-246.

Maheshwari, V., I. Vandewalle, and D. Bamber. 2011. Place branding's role in sustainable development. Journal of Place Management and Development 4 (2): 198-213.

Matzler, K., E. Sauerwein, and K. Heischmidt. 2003. Importanceperformance analysis revisited: The role of the factor structure of customer satisfaction. The Service Industries Journal 23 (2): $112-129$.

Merrilees, B., D. Miller, and C. Herington. 2012. Multiple stakeholders and multiple city brand meanings. European Journal of Marketing 46 (7/8): 1032-1047.

Mori, K., and A. Christodoulou. 2012. Review of sustainability indices and indicators: Towards a new City Sustainability Index (CSI). Environmental Impact Assessment Review 32 (1): 94-106.

Nadiri, H., and C. Tanova. 2010. An investigation of the role of justice in turnover intentions, job satisfaction, and organizational citizenship behavior in hospitality industry. International Journal of Hospitality Management 29 (1): 33-41.

Nieminen, M., and K. Hyytinen. 2015. Future-oriented impact assessment: Supporting strategic decision-making in complex sociotechnical environments. Evaluation 21 (4): 448-461.

Organ, D.W. 1988. Organizational citizenship behavior: The good soldier syndrome. Lexington: Lexington Books.

Pant, D.R. 2005. A place brand strategy for the Republic of Armenia: 'Quality of context' and 'sustainability' as competitive advantage. Place Branding and Public Diplomacy 1 (3): 273-282.

Pickett, S., C.G. Boone, B.P. McGrath, M. Cadenasso, D.L. Childers, L.A. Ogden, and J.M. Grove. 2013. Ecological science and transformation to the sustainable city. Cities 32: S10-S20.

Pike, S. 2009. Destination brand positions of a competitive set of nearhome destinations. Tourism Management 30 (6): 857-866.

Pires, S.M., T. Fidélis, and T.B. Ramos. 2014. Measuring and comparing local sustainable development through common indicators: Constraints and achievements in practice. Cities 39: 1-9.

Podsakoff, P.M., S.B. MacKenzie, J.B. Paine, and D.G. Bachrach. 2000. Organizational citizenship behaviors: A critical review of the theoretical and empirical literature and suggestions for future research. Journal of Management 26 (3): 513-563.

Project Oslo Region. (2015). The Oslo region brand management strategy. Retrieved from Oslo.

Rius Ulldemolins, J. 2014. Culture and authenticity in urban regeneration processes: Place branding in central Barcelona. Urban Studies 51 (14): 3026-3045.

Ryan, M.M., and K. Mizerski. 2010. Place branding for sustainable futures: A case study. Place Branding and Public Diplomacy 6 (1): 49-57.

Shen, L., and J. Zhou. 2014. Examining the effectiveness of indicators for guiding sustainable urbanization in China. Habitat International 44: 111-120.

Shen, L.-Y., J.J. Ochoa, M.N. Shah, and X. Zhang. 2011. The application of urban sustainability indicators-A comparison between various practices. Habitat International 35 (1): 17-29.

Sturm, R., and D.A. Cohen. 2004. Suburban sprawl and physical and mental health. Public health 118 (7): 488-496.
Sukholthaman, P., K. Shirahada, and A. Sharp. 2017. Toward effective multi-sector partnership: A case of municipal solid waste management service provision in Bangkok. Thailand. Kasetsart Journal of Social Sciences 38 (3): 324-330.

Taecharungroj, V. 2016. City ambassadorship and citizenship behaviours: Modelling resident behaviours that help cities grow. Journal of Place Management and Development 9 (3): 331-350.

Taecharungroj, V., T. Tachapattaworakul Suksaroj, and C. Rattanapan. 2018. The place sustainability scale: Measuring residents' perceptions of the sustainability of a town. Journal of Place Management and Development 11 (4): 370-390.

Tanguay, G.A., J. Rajaonson, J.-F. Lefebvre, and P. Lanoie. 2010. Measuring the sustainability of cities: An analysis of the use of local indicators. Ecological Indicators 10 (2): 407-418.

Terrados, J., G. Almonacid, and L. Hontoria. 2007. Regional energy planning through SWOT analysis and strategic planning tools: Impact on renewables development. Renewable and Sustainable Energy Reviews 11 (6): 1275-1287.

Thompson, A.B. 2003. Brand positioning and brand creation. In Brands and Branding, ed. R. Clifton and J. Simmons, 79-95. London: Economist.

Vandegrift, D., and T. Yoked. 2004. Obesity rates, income, and suburban sprawl: An analysis of US states. Health \& Place 10 (3): 221-229.

Vanolo, A. 2008. The image of the creative city: Some reflections on urban branding in Turin. Cities 25 (6): 370-382.

Vertesi, J. 2008. Mind the gap the london underground map and users' representations of urban space. Social Studies of Science 38 (1): 7-33.

Virgo, B., and L. De Chernatony. 2006. Delphic brand visioning to align stakeholder buy-into the City of Birmingham brand. The Journal of Brand Management 13 (6): 379-392.

von Friedrichs Grängsjö, Y. 2003. Destination networking: Coopetition in peripheral surroundings. International Journal of Physical Distribution \& Logistics Management 33 (5): 427-448.

Walker, S. 2016. Urban agriculture and the sustainability fix in Vancouver and Detroit. Urban Geography 37 (2): 163-182.

WCED. (1987). Our common future. Retrieved from http://www. un-documents.net/our-common-future.pdf.

Willige, A. (2017). How green is your city? These maps compare green spaces around the world. Retrieved from https://www. weforum.org/agenda/2017/01/these-interactive-maps-show-yougreen-space-in-cities-around-the-world/.

Zavattaro, S.M. 2014. Re-imagining the sustainability narrative in US cities. Journal of Place Management and Development 7 (3): 189-205.

Zeemering, E.S. 2009. What does sustainability mean to city officials? Urban Affairs Review 45 (2): 247-273.

Zhang, L., and S.X. Zhao. 2009. City branding and the Olympic effect: A case study of Beijing. Cities 26 (5): 245-254.

Publisher's Note Springer Nature remains neutral with regard to jurisdictional claims in published maps and institutional affiliations.

Viriya Taecharungroj is an assistant professor of marketing at Mahidol University International College, Thailand. He received a DPA from National Institute of Development Administration, Thailand; MA in Publishing from the University of the Arts, London; MSc in Marketing Management from the University of Surrey and BA in Economics from Thammasat University. He teaches in the areas of global marketing strategy and research. His research focuses on the areas of place branding and marketing. 
Morakot Muthuta is a lecturer in liberal arts of King Mongkut's Institute of Technology Ladkrabang, Thailand. She earned a doctoral degree in Public Administration (DPA) from National Institute of Development Administration, Thailand, MBA (International Business) from Siam University, and BA in Political Science from Kasetsart University. She specialises in the areas of public policy, local administration and international relations.
Pheereeya Boonchaiyapruek is a lecturer at the Department of Urban Design and Planning urban design. She received a PhD in Urban Form and Society from Space Syntax Laboratory, The Bartlett School of Built Environment, University College London, UK. She teaches in urban design practice while her research focuses on the relationship between urban form, socio-economic changes and urban identity. 